\title{
Effects of oophorectomy on the lumbar spine of Wistar rats submitted to vibratory platform treatment
}

\author{
Alana Ludemila de Freitas Tavares' ${ }^{1}$ Ana Luiza Peretti' ${ }^{1}$ Camila Mayumi Martin Kakihata' , Morgana Neves' \\ Christian Giampietro Brandão' ${ }^{1}$, Mário Jefferson Quirino Louzada², Rose Meire Costa' ${ }^{1}$ Lucinéia de Fátima Chasko Ribeiro', \\ Gladson Ricardo Flor Bertolini ${ }^{1}$
}

'Universidade Estadual do Oeste do Paraná - Unioeste. ${ }^{2}$ Centro Universitário Católico Salesiano - UniSalesiano.

doi: 10.18176/archmeddeporte.0006

Recibido: 04/11/2019

Aceptado: 23/09/2020

Key words:

Osteoporosis. Menopause.

Vibration. Exercise therapy.

Physical therapy modalities.

\section{Summary}

Introduction: This study evaluated the effect of the vibratory platform on the lumbar spine morphology of Wistar rats submitted to hormonal deprivation by oophorectomy.

Material and method: Twenty rats were divided into four groups: Pseudo-oophorectomy (GP), Pseudo-oophorectomy Treated (GPT), Oophorectomy (GO), Oophorectomy Treated (GOT). After 60 days of postoperative, the treated groups started exercises on a vibratory platform in the frequency parameters of $60 \mathrm{~Hz}$, alternating vibration with amplitude of $2 \mathrm{~mm}$, acceleration of $57.6 \mathrm{~m} / \mathrm{s}^{2}$ and time of 10 minutes, three times in the during the four week period. Following the euthanasia of the animals, the lumbar spine was dissected and processed for analysis of the anterior and posterior longitudinal ligaments, intervertebral disc height (IVD), nucleus pulposus (NP) height, radiographic density of the lumbar vertebrae and IVD morphology.

Results: The results showed a decrease in the height of the NP associated to the GO and morphological alterations such as lamellar disorganization and presence of rifts in the fibrous ring, alterations of the structural limits and decrease of the NP cavity; while the other groups presented organized lamellae, peripheral and nuclear region well delimited and wide cavity of the nucleus.

Conclusion: In this way, it can be concluded that the oophorectomy protocol promoted a decrease in the height of the NP of the IVD and that the exercise in the vibratory platform did not generate lesions in the analyzed tissues, as well as preserved the structural organization of the IVD and the height of the NP of oophorectomized rats.

\section{Efectos de la ooforectomía en la columna lumbar de las ratas de Wistar sometidas a tratamiento con plataforma vibratoria}

\section{Resumen}

Introducción: Este estudio evaluó el efecto de la plataforma vibratoria sobre la morfología de la columna lumbar de las ratas de Wistar sometidas a privación hormonal por ooforectomía.

Material y método: Veinte ratas fueron divididas en cuatro grupos: Pseudo-ooforectomía (GP), Pseudo-ooforectomía tratada (GPT), Ooforectomía (GO), Ooforectomía tratada (GOT). Después de 60 días de postoperatorio, los grupos tratados iniciaron los ejercicios en una plataforma vibratoria en los parámetros de frecuencia de $60 \mathrm{~Hz}$, alternando vibración con amplitud de $2 \mathrm{~mm}$, aceleración de 57,6 m/s $\mathrm{s}^{2}$ tiempo de 10 minutos, tres veces en el período de cuatro semanas. Tras la eutanasia de los animales, la columna lumbar fue diseccionada y procesada para el análisis de los ligamentos longitudinales anteriores y posteriores, la altura del disco intervertebral (DIV), la altura del núcleo pulposo (NP), la densidad radiográfica de las vértebras lumbares y la morfología del DIV.

Resultados: Los resultados mostraron una disminución en la altura del PN asociado al GO y alteraciones morfológicas tales como desorganización laminar y presencia de fisuras en el anillo fibroso, alteraciones de los límites estructurales y disminución de la cavidad del PN; mientras que los otros grupos presentaron láminas organizadas, región periférica y nuclear bien delimitadas y amplia cavidad del núcleo.

Palabras clave:

Osteoporosis. Menopausia. Vibración.

Terapia por ejercicio. Modalidades de fisioterapia.
Conclusión: De esta manera, se puede concluir que el protocolo de ooforectomía promovió una disminución en la altura del PN de la IVD y que el ejercicio en la plataforma vibratoria no generó lesiones en los tejidos analizados, además de preservar la organización estructural de la IVD y la altura de la NP de las ratas ooforectomizadas.

Correspondencia: Gladson Ricardo Flor Bertolini

E-mail: gladsonricardo@gmail.com 


\section{Introduction}

The increase in life expectancy has led to the growth of the world's aging population and, therefore, there has been an increase in the number of age-related degenerative diseases that modify vital body structures, such as the bone system?'. Osteoporosis is a systemic disease that manifests itself strongly in the skeletal system, restricting the process of bone mineralization, which contributes to the destruction of its microarchitecture ${ }^{2,3}$. The individual develops a greater risk of suffering fractures with consequent complications, putting their functionality at risk ${ }^{4,5}$

The clinical manifestation of osteoporosis in women correlates with the menopausal period, a female physiological condition characterized by a decrease in the production of estrogen and progesterone, substantial hormones of skeletal maintenance ${ }^{6}$. In these circumstances, the bone resorption process becomes more pronounced than the one of synthesis, generating a structural imbalance, an important factor in the characterization of the disease ${ }^{7,8}$. There is an expected that $50 \%$ of women after 50 years of age will suffer from a fracture caused by low bone mineral density, with vertebral injuries being more frequent ${ }^{9}$. After the initial episode, which in turn may be asymptomatic, the individual is exposed to the risk of developing additional fractures ${ }^{10}$.

Among the forms of treatment and prevention of this skeletal dysfunction is the use of pharmacological therapy with medications, supplements or even replacement therapy with synthetic hormones ${ }^{11,12}$. However, these methods sometimes require the need for daily injections and are related to ineffectiveness or acute side effects, such as musculoskeletal pain and gastrointestinal symptoms, and in the long term by vascular diseases or even breast carcinoma ${ }^{13,14}$.

Thus, it is recommended to practice physical exercises for bone maintenance, this being the main non-pharmacological intervention for the prevention and symptomatic treatment of osteoporosis, assisting in bone structural repair as well as gain of strength and resistance and adjacent structures stability, providing systemic benefits ${ }^{15,16}$. Physical exercise directly interferes with modifiable risk factors, such as obesity, sedentary lifestyle, and consequent hormonal disturbances that favors the establishment of osteoporosis, acting on the maintenance of lean mass and bone mineral density ${ }^{17,18}$.

Among the treatment modalities, the whole-body vibration (WBV) presents as an alternative to developing better cardiovascular (increase in blood flow, vasodilation due to NO release and reduction of endothelin-1 levels, sympathetic-vagal balance) and neuromuscular conditions, due to the vibration tonic reflex causing excitement of muscle spindles, generating slow and fast fiber hypertrophy, increased hormone secretion and proprioceptive stimulation ${ }^{19,20}$. By means of oscillations generated by the equipment, mechanical stimuli are produced in the body, which in turn, generate a mechanical load that promotes an anabolic bone response by the action of the piezoelectric effect, making the bone structure more resistant to loads ${ }^{20,21}$.

However, biodynamic responses to vibration depend on pre-set treatment parameters. Since the vibration magnitude varies as the oscillation attenuation occurs and also diverges according to the tissue location and composition ${ }^{19,22}$. Studies have shown that vibration can cause deleterious effects on the vertebral column, reproductive, visual and auditory systems due to the resonance phenomenon, then careful evaluation is necessary for the safe use of WBV 23,24 .

In view of the above, there is necessary to have research that ensures treatment resources for the most susceptible individuals, among them, the population with osteoporosis. The literature also presents an extensive range of treatment parameters, making bone synthesis and muscle anabolism possible, but the WBV action on the connective tissue is still not well elucidated. The aims of the study were to verify the effects of hormonal deprivation and treatment with WBV on the histomorphometry of the anterior and posterior longitudinal ligaments, intervertebral discs of the lumbar spine and the radiographic density of the lumbar vertebrae of Wistar rats submitted to oophorectomy.

\section{Material and method}

This study characterizes as experimental, transversal and quantitative. It was developing at the Universidade Estadual do Oeste do Paraná (UNIOESTE). The project was conducted according to the international standards of ethics in animal experimentation and approved by the Ethics Committee in Animal Use of UNIOESTE.

\section{Sample}

The sample group consisted of 20 female Wistar rats, nulliparous, with mean weight and initial age of $177.20 \pm 16.32 \mathrm{~g}$ and $8 \pm 1$ weeks, respectively, kept in standard polypropylene boxes in temperature of $23 \pm 1^{\circ} \mathrm{C}$, with a photoperiod of 12 hours, receiving water and feed ad libitum.

The animals were randomly distributed in the pseudo-oophorectomy (PGs) and oophorectomy (OGs) groups, both with 10 animals each. These two groups were further subdivided into two other groups:

PGs ( $n=10)$ - pseudo-oophorectomized and subdivided animals: $P G(n=5)$ - only submitted to pseudo-oophorectomy, euthanized at 4 weeks.

VPG $(n=5)$ - undergoing pseudo-oophorectomy and vibrating platform for 4 weeks.

OGs $(n=10)$ - animals submitted to oophorectomy and subdivided: OG $(n=5)$ - only submitted to oophorectomy, euthanized at 4 weeks.

VOG $(n=5)$ - undergoing oophorectomy and vibrating platform for 4 weeks.

The development process of the study occurred after performing oophorectomy and pseudo-oophorectomy surgery, followed by the vibratory platform training for four weeks, ending with euthanasia and collection of the biological material for histological analysis.

\section{Protocol of oophorectomy and pseudo-oophorectomy}

For oophorectomy, pseudo-oophorectomy and euthanasia, the rats were weighed and submitted to an anesthesia protocol consisting of intraperitoneal injection with ketamine hydrochloride (Dopalen - Ceva, Brazil) $100 \mathrm{mg} / \mathrm{kg}$ ) and xylazine (Anasedan - Ceva, Brazil) 50mg/kg). 
Oophorectomy and pseudo-oophorectomy procedures were done in the 8th week of life of the animals. After anesthesia, the trichotomy and asepsis were performed with iodinated alcohol in the lower belly, then a longitudinal surgical incision was performed with a scalpel blade number 11. After accessing the peritoneal cavity, the adipose tissue was removed until the uterine tubes and ovaries. Then, a simple catgut 4.0 wire sutures was performed in the uterine horn area, promoting the resection of the ovaries bilateral. At the end of the procedure, internal suture was performed with a single catgut 4.0 resorbable wire and external ones with nylon 4.0. This protocol is the most suitable for performing oophorectomy in experimental models because it is easy, fast and allows a better recovery for the animals ${ }^{25}$.

Pseudo-oophorectomy consisted of performing all surgical steps similar to oophorectomy, with the exception of removal of the ovaries. It was considered the control group, but its purpose is to subject the animals to the same stress caused by the surgery. Subsequent to this process, the rats remained for 60 days without any intervention, free in the cage for the induction period of the effects of the hormonal deficit.

\section{Vibratory platform protocol}

For WBV treatment, the Arktus $^{\oplus}$ (Brazil) professional tri-plane oscillating vibration platform was used. The protocol used was adapted from Butezloff et al. ${ }^{26}$, using $60 \mathrm{~Hz}$ frequency and indirect alternating sine-wave vibrations, with an amplitude of 2 millimeters, acceleration of $57.6 \mathrm{~m} / \mathrm{s}^{2}$, for 10 minutes, three times a week. The treatment started from the $9^{\text {th }}$ to the $12^{\text {th }}$ postoperative week with a duration of 4 weeks.

A support developed by the researchers was utilized according to the dimensions of the vibration platform. The use of support was designed to contain the animal during the treatment with the vibration and to allow the accomplishment of the training with several animals simultaneously. This support was made with MDF wood, white, and allowed to position eight animals concomitantly in the stalls $(13 \mathrm{~cm}$ wide, $19 \mathrm{~cm}$ long and $25 \mathrm{~cm}$ high). Also, in order to minimize a possible bias regarding the positioning of the animals on different areas of the platform, a rotation between the bays was made, causing the animals to alternate their place of residence during training. The apparatus was put on the platform avoiding contact with the surface so as not to hinder the amplitude. Groups PG and OG were also positioned on the apparatus without the vibration.

\section{Histomorphometric analysis}

\section{Thickness of anterior and posterior longitudinal ligament}

For histomorphometric analysis the lumbar vertebrae were dissected, fixed at $10 \%$ buffered formalin for 24 hours, at room temperature. Subsequently, decalcification was performed with $5 \%$ trichloroacetic acid for 25 days. After that time, the bones were washed for 1 hour with running water and 1 hour with distilled water, cleaved longitudinally, dehydrated, diaphanized and embedded in histological paraffin to be sectioned at a thickness of 7 micrometers ( $\mu$ m), using a histological microtome. After the blades were prepared, they were stained with hematoxylin-eosin (HE). The images were obtained by photomicrography and analyzed in the program Image-Pro Plus version 6.0 (Media Cybernetics, USA).
Figure 1. (A) Illustrative representation of the quadrants selected for analysis of anterior (ALL) and posterior (PLL) longitudinal ligaments in the upper (U) and lower (L) quadrants. (B) Photomicrography of the posterior longitudinal Wistar rat ligament, hematoxylin and eosin staining. Demonstration of thickness measurement (yellow line).
A

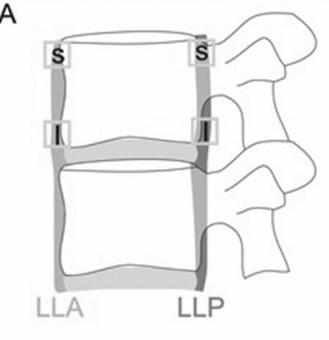

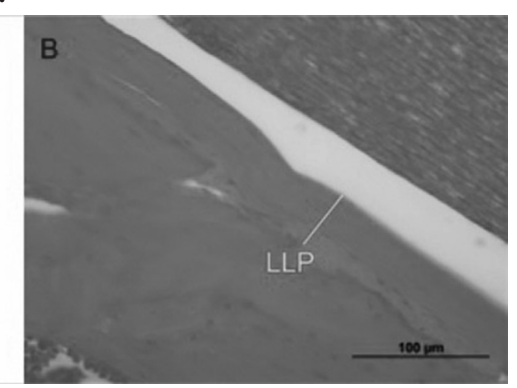

Each lumbar vertebra was analyzed in four quadrants: two quadrants for Anterior Longitudinal Ligament (ALL - upper and lower) and two in the Posterior Longitudinal Ligament ( $P L L$ - upper and lower). The images were obtained at a magnification of 400x, just below the articular cartilage and the apparent chondrocyte concentration, for the superior images, and immediately above the articular cartilage and the apparent chondrocyte concentration, for the inferior images ${ }^{27}$. The thickness of the longitudinal ligaments was obtained from the 5th lumbar vertebrae, drawing a line to measure its width in micrometers $(\mu \mathrm{m})$ and positioned at the center of the image at 50\% zoom using Image Pro Plus 6.0 program (Media Cybernetics, USA). In the presence of space in the ligaments, resulting from the artifacts, was not considered in the total measure. Morphological analysis was performed in each quadrant, observing the presence of chondrocytes between connective tissue fibers and the presence of neovascularization (Figure 1).

\section{Intervertebral disc and nucleus pulposus}

The visual fields of interest in the slides were selected and the images were recorded in the 10x magnification for the intervertebral disc (IVD) and the nucleus pulposus (NP). The images obtained was recorded in JPEG format and analyzed in the Image-Pro-Plus version 6.0 $0^{\oplus}$ (Media Cybernetics, USA).

In the measurement of the IVD, a distance of $1.0 \mathrm{~mm}$ from the PLL was used for standardization to measure $\mathrm{H} 1$ (height of the posterior portion of the disc); and from the ALL for the measurement of $\mathrm{H} 3$ (height of the anterior portion of the disc); $\mathrm{H} 2$ and $\mathrm{H} 4$ were measured from the midpoint of the width of the DIV for the verification of the disk height and the NP height and area, respectively (Figure 2).

\section{Histology of the intervertebral disc}

For the analysis of the IVD, the morphology of the fibrous ring (FR) and NP were assessed in relation to the histologic pattern of normality or presence of alterations ${ }^{28}$.

\section{Radiographic density analysis}

Radiographies measurements were performed on the lumbar spine segment after collection of the lumbar segment using a $x$-ray equipment 
Figure 2. Photomicrograph representing the analysis of the height of the intervertebral disc, in the anterior $(\mathrm{H} 1)$, middle $(\mathrm{H} 2)$, posterior (H3) and nucleus pulposus (H4).

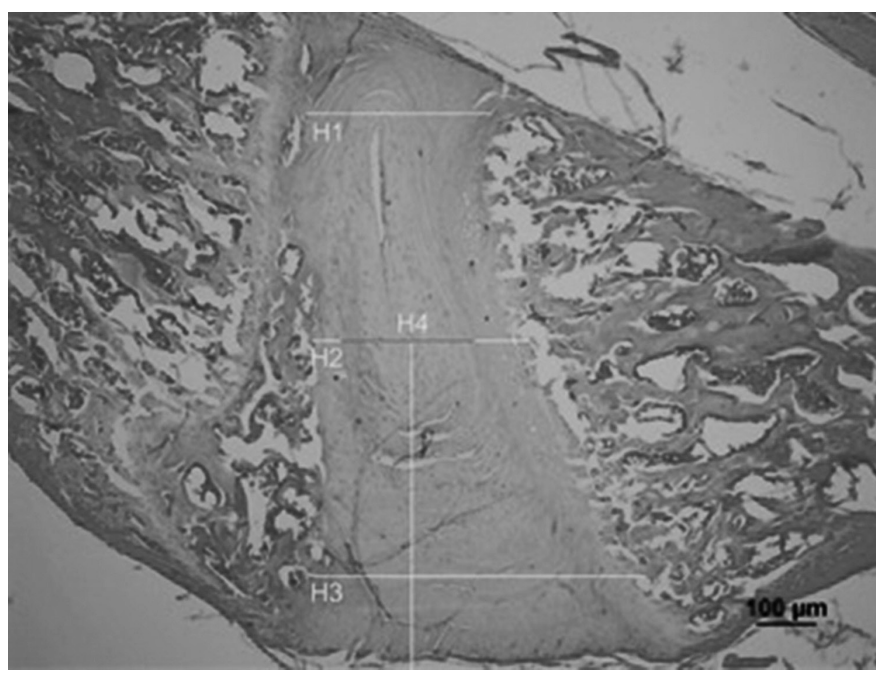

(Gnatus, Brazil), 70 kVp-7 mA, with a focus-sensor distance of $250 \mathrm{~mm}$, for an exposure time of 0.6 seconds and axis positioned perpendicular to the material. The direct digital image was generated using the Kodak Dental Imaging Software - 6.12.32.0 (Kodak, USA), connected to a sensor where the lumbar segment was positioned on its surface. For the densitometry reference, an eight-step aluminum penetrometer was placed parallel to the vertebrae also on the sensor, towards the main
X-ray beam. The digitized images were saved with TIFF extension for better resolution during subsequent analysis.

The evaluation of bone radiopacity was performed using the Image J (National Institute of Health, USA) program, calibrated to select 8 aluminum steps for measuring the amount of gray tone of the material ${ }^{29}$ A region of interest of $60 \times 20$ pixels was delimited for quantification of gray tone present in the body of the fifth lumbar vertebra of animals in all groups ${ }^{30}$. The results were tabulated using the Microsoft Excel $2013^{\circledR}$ (Microsoft, USA) program and, therefore, the radiographic density was expressed in millimeters of aluminum (mmAl) after subsequent conversion $^{31}$.

\section{Statistical analysis}

The SPSS 20.0 (IBM, USA) program was used to perform the statistical analysis. The data were presented in mean and standard error, in addition to the confidence interval (95\%), the inferential analysis was performed with the Generalized Linear Models test and the LSD posttest (Fisher's Least Significant Difference), in both cases the accepted significance level was $5 \%$.

\section{Results}

By means of the averages of the ligament thicknesses of the upper and lower regions, it was observed that for the LLA in its upper portion, the VPG showed values higher than VOG. In the mean values, there was also a difference in LLA, and VOG showed lower values than the other groups (Table 1).

Table 1. Mean and standard error (below confidence interval) of the thicknesses of the anterior and posterior longitudinal ligaments of upper and lower vertebral region and total means by ligament.

\begin{tabular}{|c|c|c|c|c|}
\hline & PG & VPG & OG & VOG \\
\hline ALL & $237.45 \pm 24.09$ & $304.67 \pm 30.92$ & $238.00 \pm 24.15$ & $195.38 \pm 19.83 a$ \\
\hline Upp & $194.63-289.70$ & $249.72-371.71$ & $195.08-290.37$ & $160.14-290.37$ \\
\hline$p$-value & & & & \\
\hline ALL & $245.92 \pm 36.21$ & $234.65 \pm 34.55$ & $253.25 \pm 37.29$ & $177.29 \pm 26.10$ \\
\hline Low & $184.28-328.19$ & $184.28-328.19$ & $189.77-337.96$ & $184.28-328.19$ \\
\hline$p$-value & & & & \\
\hline PLL & $269.84 \pm 30.51$ & $232.12 \pm 26.25$ & $256.84 \pm 29.04$ & $252.71 \pm 28.57$ \\
\hline Upp & $216.20-336.78$ & $185.98-289.71$ & $205.79-320.56$ & $202.48-315.41$ \\
\hline$p$-value & & & & \\
\hline PLL & $253.49 \pm 27.27$ & $254.03 \pm 27.33$ & $283.97 \pm 30.55$ & $215.87 \pm 23.22$ \\
\hline Low & $205.30-312.98$ & $205.30-312.98$ & $229.99-350.62$ & $174.84-266.53$ \\
\hline$p$-value & & & & \\
\hline ALL & $\begin{array}{c}241.69 \pm 21.35 \\
203.27-287.37\end{array}$ & $\begin{array}{c}269.66 \pm 23.82 \\
226.79-320.64\end{array}$ & $\begin{array}{c}245.62 \pm 21.70 \\
206.58-292.05\end{array}$ & $\begin{array}{c}186.34 \pm 16.46 b \\
156.71-221.56\end{array}$ \\
\hline$p$-value & & & & \\
\hline PLL & $\begin{array}{c}261.66 \pm 24.25 \\
218.03-314.03\end{array}$ & $\begin{array}{c}243.08 \pm 22.62 \\
202.55-291.73\end{array}$ & $\begin{array}{c}270.41 \pm 25.17 \\
225.32-324.52\end{array}$ & $\begin{array}{c}234.29 \pm 21.81 \\
195.22-281.18\end{array}$ \\
\hline p-value & & & & \\
\hline
\end{tabular}

a - difference between VGP and VOG ALL Upp ( $p=0.003)$. b - difference between VOG with PG (0.040), VPG (0.004) and OG ( $p=0.029)$. 
Table 2. Means and standard error (below confidence interval) of the measurement of the intervertebral disc height, as to the height of the nucleus pulposus and the intervertebral disc: an anterior portion, middle portion and a posterior portion.

\begin{tabular}{lcccc}
\hline & PG & VPG & OG & VOG \\
\hline NP & $13.62 \pm 1.31$ & $15.01 \pm 1.45$ & $13.42 \pm 1.29$ & $18.57 \pm 1.79$ \\
& $11.28-16.45$ & $12.43-18.13$ & $11.11-16.21$ & $15.37-22.43$ \\
p-value & & 0.065 & \\
& & 4 & \\
Anterior & $54.60 \pm 4.72$ & $58.82 \pm 4.72$ & $53.12 \pm 4.72$ & $59.03 \pm 4.72$ \\
& $45.34-63.86$ & $49.56-68.08$ & $43.86-62.38$ & $49.77-68.28$ \\
p-value & & 0.753 & \\
Medium & $34.99 \pm 2.22$ & $39.12 \pm 2.49$ & $37.12 \pm 2.36$ & $34.44 \pm 2.19$ \\
& $30.89-39.64$ & $34.53-44.31$ & $32.77-42.05$ & $30.40-39.01$ \\
p-value & & 0.471 & \\
Posterior & $29.56 \pm 2.64$ & $29.87 \pm 2.67$ & $26.14 \pm 2.34$ & $35.52 \pm 3.18$ \\
p-value & $24.81-35.21$ & $25.07-35.59$ & $21.94-31.14$ & $29.81-42.32$ \\
& & 0.113 & \\
\hline
\end{tabular}

Table 3. Means and standard error (below confidence interval) for radiographic density (RD) analysis.

\begin{tabular}{|c|c|c|c|c|}
\hline & PG & VPG & OG & VOG \\
\hline $\mathrm{RD}$ & $\begin{array}{c}13.36 \pm 0.63 \\
12.19-14.64\end{array}$ & $\begin{array}{c}13.43 \pm 0.63 \\
12.26-14.73\end{array}$ & $\begin{array}{c}12.69 \pm 0.59 \\
11.57-13.91\end{array}$ & $\begin{array}{r}12.81 \pm 0.60 \\
11.69-14.04\end{array}$ \\
\hline \multicolumn{2}{|c|}{$\mathrm{p}$-value } & \multicolumn{2}{|c|}{0.766} & \\
\hline
\end{tabular}

No morphological alterations were identified in the ligaments, such as neovascularization, chondrocyte invasion or the presence of other cells in the connective tissue medium in the analyzed regions.

For an analysis of the intervertebral disc height, there was no statistical difference (Table 2).

Regarding the radiographic density analysis, there were no differences between groups as showed in Table 3 .

In the morphological analysis of the PG and VPG, the IVD presented normal appearance, with concentric layers of fibrocartilage forming the FR around the NP, discrete lamellae with bulging and without folds. NP formed by cells immersed in viscous extracellular matrix with large bulging of the central cavity, which represents about two-thirds of the height of the IVD (Figure 3).

The OG, presented alteration of the FR in the presence of opposite lamellae and the presence of small folds and oblique and transverse gaps. In the NP, it was verified a reduction of the cavity size, being smaller than one third of the height of the IVD, and alteration of the structural borders, which were poorly delimited.

The VOG also presented alterations in the organization of the connective tissue of the FR with slightly opposing lamellas, but better organizational structure. NP maintained a nuclear aspect similar to that of groups without hormonal deprivation.
Figure 3. Photomicrographs of the lumbar spine intervertebral disc of Wistars rats, longitudinal section, $7 \mu \mathrm{m}$, hematoxylin and eosin staining. In PG, pseudo-oophorectomized rats and VPG, treated pseudo-oophorectomized rats, with presence of the nucleus pulposus (NP), with due bulging, height and sharpness of the morphological limits, and fibrous ring (AF), with well disposed lamellae, without folds and presence of gaps. In OG, oophorectomized rats, presenting opposite lamellae, oblique and transverse gaps (asterisks) and cavity of the nucleus pulposus decreased and, in VOG, oophorectomized rats submitted to the vibratory treatment with the presence of slight lamellar opposition, but better disposed with preservation of the nuclear cavity.

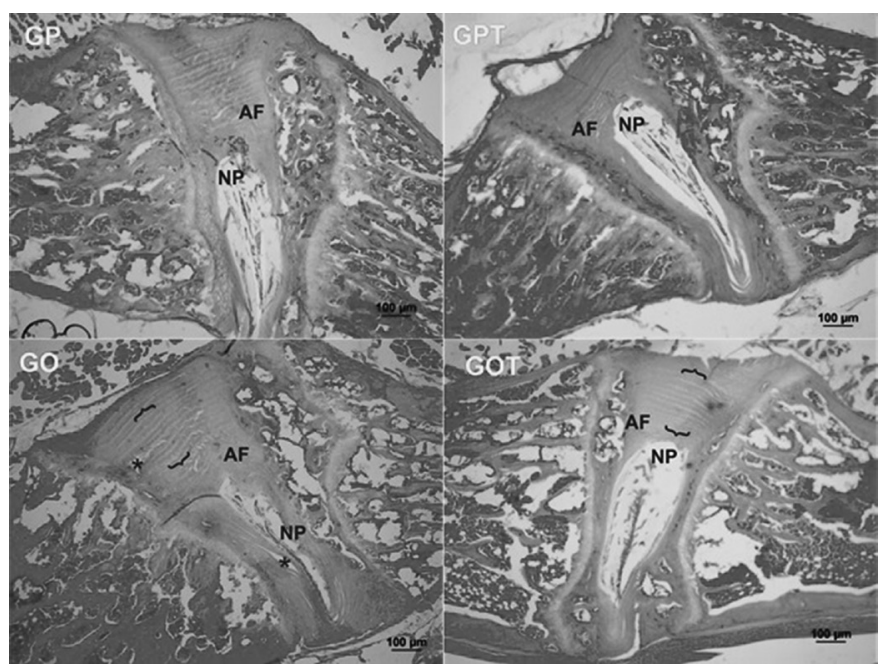

\section{Discussion}

The present study indicated that there were alterations at the ALL thickness of the animals submitted to hormonal deprivation and WBV. Research shows that individuals with metabolic disorders present osteoporosis, with stiffening and thickening of the posterior longitudinal ligament from the age of forty years. However, there are not any data to indicate the onset of morphological changes after instilling injury 32,33 . Since changes have been observed that point to a reduction in the thickness of the ALL, it may be an indication of positive effects, i.e. although it decreases in thickness, it does not mean that it is less resistant, mainly because other characteristics have not been observed that worsen mechanical stress.

In the Simas et al.' study, rats with 60 days of oophorectomy, presented deleterious effects of the upper cartilage tissue of the tibia with a decrease in their thickness, proving that this period of hormonal deprivation is efficient to assign negative alterations to the connective tissue. The same postoperative period was also used in the present study, but just metrical differences were observed in the ALL. In a degenerative process such as osteoporosis, spinal-related ligaments and IVD suffer a chondrocyte invasion and proliferation of fibroblast-like spindle cells that make the connective structures more rigid, thicker and less resistant to mechanical stress ${ }^{34,35}$. 
For an analysis of the IVD height, no statistical differences between the groups were observed. Studies show that in osteoporotic individuals, who develop lumbar fractures, presents a narrowing of the IVD space, which is a risk factor for spinal biomechanics, due to the increase in vertical load on the peduncle and the articular facets ${ }^{21,36}$.

At age-related changes or in the presence of degenerative diseases, IVD dehydration occurs where FR gets cracks in the boundaries between the periphery and the nucleus and the NP becomes more rigid. NP is a more susceptible structure because its anatomical location gives it greater exposure to stress when opposed to other connective tissues ${ }^{37}$. In this research, it was possible to observe that the OG obtained a lower NP height when compared to the other groups. On the other hand, VOG did not show statistical differences and this was a sign that the WBV preserved the central region more susceptible to IVD.

It has been hypothesized that exercise has not only favored the maintenance of the disc collagen. But also produced benefits to the stabilizing structures of the lumbar spine, since vibratory stimulations generate excitation of the primary muscle spindle through afferent type la neurons, producing a vibration tonic reflex ${ }^{38}$. This, contributes to the maintenance of muscle strength as well as maintenance of joint positioning $^{39}$.

McCann et al..$^{40}$ subjected mice to $45 \mathrm{HzWBV}, 74 \mu \mathrm{m}$ peak-to-peak amplitude, 30 minutes a day, 5 days a week for 2, 4, and 8 weeks. The results showed that the group submitted to the 4-week treatment obtained a decrease in the height of the IVD. In a comparison of the parameters used, treatment protocol presented similar duration, but with less frequency and with only two days of interval between weeks of treatment. Thus, the frequency of $60 \mathrm{~Hz}$ associated with the treatment with a 1-day rest interval and in the period of only 10 minutes of time did not promote detrimental changes at the time of IVD, demonstrating at a safe range for the VPG and VOG.

Recently the therapeutic vibratory treatment demonstrated anabolic effects on several tissues, especially muscles and bones ${ }^{34}$. Due to its low biomechanical impact and the lack of great mobility and strength of the individual being treated. This resource presents itself as an exercise modality, pertinent to the aging population, individuals with neurological alterations and metabolic syndromes that commonly have difficulties to perform physical activities or impact ${ }^{41,42}$.

The WBV is gaining more and more interest, due to the benefits that the modality presents to the varied corporeal tissues, of these it is emphasized the proprioceptive improvement, modulation of the reflex excitability of the vertebral column and modification of the excitability of the motor cortex. Vibration is also a form of dynamic mechanical loading, being a potent stimulation of osteogenesis ${ }^{43}$.

Regarding the results obtained regarding radiographic density, no differences were observed between the analyzed groups. In the research conducted by Lam et al. ${ }^{44}$, a WBV protocol of 32 to $37 \mathrm{~Hz}$, amplitude of $0.085 \mathrm{~mm}$, during 20 minutes/day, 5 times/week, at 52 weeks, resulted in an increase in the bone mineral density of the lumbar spine, whose vibration was used to treat adolescents with osteopenia and idiopathic scoliosis, demonstrating a positive effect over a longer treatment period compared to the present study.

Pasqualini et al. ${ }^{24}$ compared the frequencies of $8 \mathrm{~Hz}, 52 \mathrm{~Hz}$ and $90 \mathrm{~Hz}, 10$ minutes, 5 days a week for 28 days on the bone tissue, analyzing the second lumbar vertebra and the tibia. Research has shown that the lower frequency produced deleterious effects on bone mineral density, $52 \mathrm{~Hz}$ optimized vertebral microarchitecture and finally, the higher frequency provided benefits for both structures. The present study demonstrated that no deleterious effects were observed on the bone segments analyzed, since the radiographic density did not vary between groups.

In the present study, it was observed that OGs showed morphological alterations of lamellar structure disorganization and limits, presence of cracks as well as noticiable reduction of internal nuclear cavities. IVD is composed of FR externally with approximately $60 \%$ collagen and internally by NP, which in addition to collagen (20\%) also presents proteoglycan proteins responsible for giving resistance and attracting water to the internal environment. The composition between collagen and proteoglycans confers the characteristic of resistance, elasticity and compressibility of articular cartilage, damping and dissipating the incoming forces and reducing friction during movements $s^{45,46}$. Metabolic syndromes or even aging lead to a decrease in proteoglycans associated with lower mechanical resistance of cartilage due to decreased hydration and increased susceptibility to collagenase ${ }^{47}$, which are the possible causes of the alterations present in the OG.

For the treated groups, the morphology of the IVD did undergo major structural modifications. Only VOG showed subtle lamellar alterations due to the probable hormonal deprivation. But with better appearance when compared to the OG. The mechanical stress on the tissue generates a piezoelectric effect that, through compression of the bone matrix, cilia and membrane receptors present in the osteocytes detect the stimulus and promote bone synthesis ${ }^{48}$.

Genetic and socioeconomic factors can act by modifying the composition of the IVD, for example, by decreasing the expression of type IX collagen that forms the support matrix. This can lead to annular fissures and promote structural and biomechanical changes favoring a degenerative process ${ }^{23,49,50}$.

McCann et al. ${ }^{51}$ performed a search on mice, submitted to $45 \mathrm{~Hz}$ vibrations, 30 minutes a day for 4 weeks. The histological analysis of a lumbar segment revealed signs of IVD degeneration, such as loss of the border between NP and FR, alterations in the disposition and disorganization of lamellar collagen and the presence of interlamellar spaces. Thus, the treatment parameters used in the present study ensured a better morphological pattern for oophorectomized rats.

There is a need for further studies that present the effect of vibratory therapy on osteoporosis as well as more extensive investigations that evaluate other tissues besides the bone and ligament, such as muscles, nerves and adjacent ligaments, in order to develop safe protocols that aid in efficient physiotherapeutic treatments as well as in the improvement of the patient quality of life. We suggest the implementation of protocols that contemplate long-term vibration in a model of hormonal deprivation, which is a limitation of this study.

\section{Conclusion}

The present study concluded that the hormonal deprivation model was an effect to promote structural alterations, added to WBV alter the 
ALL thickness at the lumbar level, but not in the radiographic density of their respective vertebrae and height of the NP, but promoted morphological alterations in the IVD.

\section{Acknowledgments}

To the Fundação Araucária for the financing of the research project (Basic and Applied Research Ed.), as well as to the Conselho Nacional de Desenvolvimento Científico e Tecnológico (CNPq), for the financing of scientific initiation fellowships.

\section{Conflict of interest}

The authors declare no conflict of interest.

\section{Bibliography}

1. Lubelski D, Choma T, Steinmetz MP, Harrop JS, Mroz TE. Perioperative medical management of spine surgery patients with osteoporosis. Neurosurgery. 2015;77(Suppl. 4):S93-7.

2. Bauer DC. Calcium supplements and fracture prevention. N Engl J Med. 2013; 369:1537-43.

3. Dodwad SNM, Khan SN. Surgical stabilization of the spine in the osteoporotic patient. Orthop Clin North Am. 2013;44:243-9.

4. Silva ACV, da Rosa MI, Fernandes B, Lumertz S, Diniz RM, dos Reis Damiani MEF. Fatores associados à osteopenia e osteoporose em mulheres submetidas à densitometria óssea. Rev Bras Reumatol. 2015;55:223-8.

5. Yates CJ, Chauchard MA, Liew D, Bucknill A, Wark JD. Bridging the osteoporosis treatment gap: Performance and cost-effectiveness of a fracture liaison service. J Clin Densitom. 2015;18:150-6.

6. Cosman F, de Beur SJ, LeBoff MS, Lewiecki EM, Tanner B, Randall S, et al. Clinician's guide to prevention and treatment of osteoporosis. Osteoporos Int. 2014;25:2359-81.

7. Simas JMM, Kunz RI, Brancalhão RMC, Ribeiro L de FC, Bertolini GRF. Effects of physical exercise on the cartilage of ovariectomized rats submitted to immobilization. Einstein (São Paulo). 2015;13:574-9.

8. Miller PD, Hattersley G, Riis BJ, Williams GC, Lau E, Russo LA, et al. Effect of abaloparatide vs placebo on new vertebral fractures in postmenopausal women with osteoporosis: a randomized clinical trial. JAMA. 2016;316:722-33.

9. Sugerman DT. Osteoporosis is the most common bone disease and is twice as common in women as in men. JAMA. 2014;311:104.

10. Cappola AR, Shoback DM. Osteoporosis therapy in postmenopausal women with high risk of fracture. JAMA. 2016;316:715-6.

11. Khajuria DK, Razdan R, Mahapatra DR. Medicamentos para o tratamento da osteoporose: Revisão. Rev Bras Reumatol. 2013;51:365-82.

12. Akita K, Harada K, Ichihara J, Takata N, Takahashi Y, Saito K. A novel selective androgen receptor modulator, NEP28, is efficacious in muscle and brain without serious side effects on prostate. Eur J Pharmacol. 2013;720:107-14.

13. Ribeiro CCM, Shimo AKK, Lopes MHB de M, Lamas JLT. Efeitos dos diferentes anticoncepcionais hormonais nos valores de pressão arterial da mulher. Rev Bras Enferm. 2018;71:1537-43

14. Patel A, Lee HO, Jawerth L, Maharana S, Jahnel M, Hein MY, et al. A liquid-to-solid phase rransition of the ALS protein FUS accelerated by disease mutation. Cell. 2015;162:106677.

15. Kunz RI, Coradini JG, Silva LI, Bertolini GRF, Brancalhão RMC, Ribeiro LFC. Effects of immobilization and remobilization on the ankle joint in Wistar rats. Brazilian J Med Biol Res. 2014;47:842-9.

16. Caputo EL, Costa MZ. Influência do exercício físico na qualidade de vida de mulheres pós-menopáusicas com osteoporose. Rev Bras Reumatol. 2014;54:467-73.

17. Hinton PS, Nigh P, Thyfault J. Effectiveness of resistance training or jumping-exercise to increase bone mineral density in men with low bone mass: A 12-month randomized, clinical trial. Bone. 2015;79:203-12.

18. Black DM, Clifford RJ. Postmenopausal osteoporosis. N Engl J Med. 2016;374:354-62.

19. Huang M, Tang C yin, Pang MYC. Use of whole body vibration in individuals with chronic stroke: Transmissibility and signal purity. J Biomech. 2018;73:80-91.
20. Park S-Y, Son W-M, Kwon O-S. Effects of whole body vibration training on body composition, skeletal muscle strength, and cardiovascular health. J Exerc Rehabil. 2015;11:289-95.

21. Cerciello S, Rossi S, Visonà E, Corona K, Oliva F. Clinical applications of vibration therapy in orthopaedic practice. Muscles Ligaments Tendons J. 2016;6:147-56.

22. Tarabini M, Solbiati S, Moschioni G, Saggin B. Analysis of nonlinear response of the human body to vertical whole-body vibration. Ergonomics. 2014;57:1-13.

23. Kerr GJ, McCann MR, Branch JK, Ratneswaran A, Pest MA, Holdsworth DW, et al. C57BL/6 mice are resistant to joint degeneration induced by whole-body vibration. Osteoarthr Cartil. 2017;25:421-5

24. Pasqualini M, Lavet C, Elbadaoui M, Vanden-Bossche A, Laroche N, Gnyubkin V, et al. Skeletal site-specific effects of whole body vibration in mature rats: From deleterious to beneficial frequency-dependent effects. Bone. 2013;55:69-77.

25. Khajuria DK, Razdan R, Mahapatra DR. Descrição de um novo método de ooforectomia em ratas. Rev Bras Reumatol. 2012;52:466-70.

26. Butezloff MM, Zamarioli A, Leoni GB, Sousa-Neto MD, Volpon JB. Whole-body vibration improves fracture healing and bone quality in rats with ovariectomy-induced osteoporosis. Acta Cirúrgica Bras. 2015;30:727-35.

27. Borges $M C D$, Errero $T K$, Rosa $C T$, Bernardino GR, Brancalhão RMC, Ribeiro $L$ de $F C$, et al. Avaliação dos ligamentos longitudinais da coluna de ratos Wistar em modelo experimental da terapia Suit TT - Evaluation of longitudinal ligament of the spine of Wistar rats in an experimental model of Suit therapy $T$ - Evaluación de los ligamentos longi. Fisioter e Pesqui. 2016;23:148-54.

28. Pereira AC de Cl, Castania V, Jong JJA, Defino HLA, Pitol DL, Del Bel E. Modelo de degeneração do disco intervertebral por punção da cauda de ratos Wistar : avaliação histológica e radiográfica. Coluna. 2010;9:455-61.

29. Antonietto E, Carvalho J De, Coêlho A, Biffe BG, Carvalhal R, Jefferson M, et al. Alterações da densidade mineral óssea em vértebras de ratos Wistar submetidos à ausência de carga nos membros pélvicos. Brazilian J Vet Res Anim Sci. 2012;49:185-92.

30. Silva AR dos S, Ribeiro ACP, Salzedas LMP, Soubhia AMP, Sundefeld MLMM, Mazza M. Análise da densidade óssea radiográfica de ratos submetidos ao alccolismo crônico utilizando imagem digital. Rev Odonto Ciência. 2007;22:77-81.

31. Louzada MJQ, Belangero WD, Martins LEB. Avaliação de parâmetros biomecânicos pela densitometria radiográfica. Estudo "In vitro" em osso cortical de tíbias de carneiros. Brazilian J Biomech. 2006;7:33-8.

32. Sohn S, Chung CK. Increased bone mineral density and decreased prevalence of osteoporosis in cervical ossification of the posterior longitudinal ligament: A casecontrol study. Calcif Tissue Int. 2013;92:28-34.

33. Tsuru M, Ono A, Umeyama H, Takeuchi M, Nagata K. Ubiquitin-dependent proteolysis of CXCL7 leads to posterior longitudinal ligament ossification. PLOS One. 2018;13:1-23.

34. Keller B V., Davis ML, Thompson WR, Dahners LE, Weinhold PS. Varying whole body vibration amplitude differentially affects tendon and ligament structural and material properties. J Biomech. 2013;46:1496-500.

35. Saetia K, Cho D, Lee S, Kim DH, Kim SD. Ossification of the posterior longitudinal ligament: a review. Neurosurg Focus. 2011 Mar;30:E1.

36. Lai C-L, Tseng S-Y, Chen C-N, Liao W-C, Wang C-H, Lee M-C, et al. Effect of 6 months of whole body vibration on lumbar spine bone density in postmenopausal women: a randomized controlled trial. Clin Interv Aging. 2013;8:1603-9.

37. Kamper M, Hamann N, Prein C, Clausen-Schaumann H, Farkas Z, Aszodi A, et al. Early changes in morphology, bone mineral density and matrix composition of vertebrae lead to disc degeneration in aged collagen IX -/- mice. Matrix Biol. 2016;49:132-43.

38. Alghadir AH, Anwer S, Zafar H, lqbal ZA. Effect of localised vibration on muscle strength in healthy adults: a systematic review. Physiotherapy. 2018;104:18-24.

39. Blackburn JT, Pamukoff DN, Sakr M, Vaughan AJ, Berkoff DJ. Whole Body and Local Muscle Vibration Reduce Artificially Induced Quadriceps Arthrogenic Inhibition. Arch Phys Med Rehabil. 2014;95:2021-8.

40. McCann MR, Yeung C, Pest MA, Ratneswaran A, Pollmann SI, Holdsworth DW, et al. Whole-body vibration of mice induces articular cartilage degeneration with minimal changes in subchondral bone. Osteoarthr Cartil. 2017;25:770-8.

41. Cheng HYK, Ju YY, Chen CL, Chuang LL, Cheng CH. Effects of whole body vibration on spasticity and lower extremity function in children with cerebral palsy. Hum Mov Sci. 2015;39:65-72.

42. Zha D, Zhu Q, Pei W, Zheng J, Wu S, Xu Z, et al. Does whole-body vibration wiith alternative tilting increase bone mineral density and change bone metabolism in senior people? Aging Clin Exp Res. 2011;24:28-36.

43. Lam FMH, Tang C yin, Kwok TCY, Pang MYC. Transmissibility and waveform purity of whole-body vibrations in older adults. Clin Biomech. 2018;51:82-90. 
44. Lam TP, Ng BKW, Cheung LWH, Lee KM. Effect of whole body vibration (WBV) therapy on bone density and bone quality in osteopenic girls with adolescent idiopathic scoliosis: a randomized, controlled trial. Osteoporos Int. 2013;24:1623-36.

45. Rossi E. Envelhecimento do sistema osteoarticular. Einstein. 2008;6:7-12.

46. Villegas, YR, Zambrano HP, Quintero JA, Mojica RP, Cabeza JP, Teherán CB, et al. Dolor discogénico lumbar: revisión literaria. Rev Chil Neurocir. 2018;44:55-9.

47. Caires $L M$, Alves F. Degeneração do disco intervertebral: Revisando conceitos. Rev NBC. 2018;6:46-59.

48. Pratap UP, Patil A, Sharma HR, Hima L, Chockalingam R, Hariharan MM, et al. Estrogeninduced neuroprotective and anti-inflammatory effects are dependent on the brain areas of middle-aged female rats. Brain Res Bull. 2016;124:238-53.
49. Kepler CK, Ponnappan RK, Tannoury CA, Risbud M V, Anderson DG. The molecular basis of intervertebral disc degeneration. Spine J . 2013;13:318-30.

50. Brachvogel B, Zaucke F, Dave K, Norris EL, Stermann J, Dayakli M, et al. Comparative proteomic analysis of normal and collagen IX null mouse cartilage reveals altered extracellular matrix composition and novel components of the collagen IX interactome. J Biol Chem. 2013;288:13481-92.

51. McCann MR, Veras MA, Yeung C, Lalli G, Patel P, Leitch KM, et al. Whole-body vibration of mice induces progressive degeneration of intervertebral discs associated with increased expression of $\|-1 \beta$ and multiple matrix degrading enzymes. Osteoarthr Cartil. 2017;25:779-89. 